\title{
REDEFINITIONS AND NOMENCLATURAL CHANGES WITHIN THE LEPTOSPERMUM SUBALLIANCE OF MYRTACEAE
}

\author{
JOY THOMPSON \\ (Accepted for publication 20.10.1982)
}

\begin{abstract}
Thompson, Joy (National Herbarium of New South Wales, Royal Botanic Gardens, Sydney, Australia, 2000) 1983. Redefinitions and Nomenclatural Changes within Leptospermoideae (Myrtaceae). Telopea 2(4): 379-383-A new genus, Neofabricia, from tropical Queensland is described and two new combinations made, $N$. myrtifolia (Gaertn.) J. Thompson and $N$. mjoebergii (Cheel) J. Thompson; the new combination Kunzea ericoides (A. Rich.) J. Thompson is made for a species from southeastern Australia and New Zealand; and two genera from Western Australia, Pericalymma (Endl.) Endl. and Homalospermum Schauer, are reinstated.
\end{abstract}

In order to complete a revision of the genus Leptospermum (Leptospermoideae, Myrtaceae) it has become necessary to take into consideration a number of species which in most treatments of the group sit uneasily on the edge of the generally accepted concept of that genus. As knowledge of the many (perhaps 80 ) taxa of the main body of Leptospermum has developed, it has become increasingly obvious that a number of these outlying species, though not unrelated, represent lines of evolution separate from that represented by Leptospermum.

To make names available for those species now excluded from Leptospermum, the new taxa, combinations and usages are set out here.

1. Kunzea Reichb. nom. gen. cons. prop.

Kunzea ericoides $(A$. Rich.) J. Thompson, comb. nov. - Leptospermum ericoides A. Rich., Voyage Découv. Astrolabe, Bot. 1: 338 (1832), basionym.-Type: in locis aridis elevatisque Novae-Zeelandiae (hâvre de l'Astrolabe), n.v. As the species is well described and based on a specimen from New Zealand, there can be no doubt as to its identity.

Baeckea phylicoides A. Cunn. ex Schauer in Walpers, Repert. Bot. Syst. 2, Suppl. 1: 921 (1843).-Leptospermum phylicoides (A. Cunn. ex Schauer) Cheel, J. \& Proc. Roy. Soc. New South Wales 76: 231 (1943).-Type: in Novae Cambriae interioribus, A. Cunningham herb. 38, n.v. A specimen in Herb. Hook., labelled "Banks of rivers, Argyle, N.H.", may be part of the Type collection. I have seen a photograph.

Kunzea peduncularis F. Muell., Trans. \& Proc. Victorian Inst. Advancem. Sci. 1: 124 (1855).-Type: at the foot of the Australian Alps, on the banks of rivers and rivulets, F. Mueller, n.v.

Kunzea leptospermoides F. Muell. ex. Miq., Ned. Kruidk. Arch. 4: 145 (1856). -Type: Brighton [? Bright, Victoria], F. Mueller, n.v.

Leptospermum sinclairii T. Kirk, Stud. Fl. New Zealand: 158 (1899).-Type: Great Barrier Island [New Zealand], Hutton \& Kirk, n.v.

This species has an androecium characteristic of Kunzea rather than Leptospermum. The filaments are long, usually in two rows, and of a different texture from those of Leptospermum. The stamens in the bud are incurved and deflexed so that they are packed into the space above the ovary and below the stigma. This contrasts with the condition in Leptospermum where, even in species with relatively 
long stamens, the filaments curve towards the stigma. Also in this species, as in other species of Kunzea (and unlike all species of Leptospermum), there is little or no thickening of cells at the back of the anther, so that when the pollen is shed the anther is left gaping. Kunzea ericoides is found in southern Queensland, New South Wales, Victoria, eastern South Australia and New Zealand; it is most closely related to $K$. ambigua (Sm.) Druce of eastern Australia and to a rare and as yet unnamed species from the north coast of New South Wales.

S.T. Blake (1958) discussed the discrimination of Kunzea and Leptospermum, and listed a number of characters by which these genera could be separated. From this enumeration it is evident that Blake was unfamiliar with a majority of species of Leptospermum, and unaware of the extent of variation within that genus. In species of Leptospermum the upper part of the hypanthium can be relatively unexpanded, the calyx-lobes herbaceous and/or persistent, the petals unclawed, or the ovules at least as broad as those of Kunzea. Kunzea ericoides is superficially very similar to some of these species but can be readily distinguished by the androecial characters given above.

\section{Neofabricia $J$. Thompson, gen. nov.}

Frutices vel abores parvae. Folia spiraliter disposita. Flores flavi vel albi, terminales vel axillares. Stamina numerosa indefinita filamentis gracilibus et antheris non versatilibus. Ovarium loculis 5 usque ad $10(-15)$. Semina alata; ala ex ovulis sterilibus constructa.

\section{Typus generis: $N$. myrtifolia (Gaertn.) J. Thompson}

Shrubs or small trees with spiral leaf-arrangement. Flowers yellow or white, occurring as monads, or rarely triads, in the axils of leaves or bracts. Stamens numerous and indefinite, with slender filaments and non-versatile anthers. Ovary with 5 to $10(-15)$ loculi, each with a number of ovules in two rows on a narrow axile placenta. Fruit a somewhat woody capsule with very convex pubescent valves. Seeds one, or several united, joined to the undeveloped ovules of the same loculus which unite to form a wing; all forming a single and rather varied compound structure. The genus consists of two species, both found in tropical Queensland.

This genus represents part of that described by Gaertner, Fruct. 1: 175, t. 35, f.4 (1788). Unfortunately the name he used was a later homonym of Fabricia Adans. (1763). In describing Fabricia, Gaertner included two species; $F$. myrtifolia, the Type species, and $F$. laevigata. Other writers, none of whom had carefully examined the Endeavour River specimen on which Gaertner's genus was based, assumed the wing of the seed to be the simple structure found in the second species, a species readily available for examination, and now considered to be a species of Leptospermum. The extraordinary structure within the loculus of the fruit of Neofabricia, which was illustrated, though not well, in Gaertner's otherwise excellent representation of Banks and Solander's Endeavour River plant, has passed unnoticed. The relative uniformity of the androecium of Leptospermum sens. str. has also remained unnoticed, so that the significance of the differences, in the anther-attachment and the stamenarrangement, between Neofabricia and the other elements in Leptospermum Sect. Fabricia as circumscribed by Bentham, Fl. Austral. 3: 102 (1867), has always been overlooked.

In order to dissociate this distinct genus from the confusion and error which has accompanied the use and misuse of Gaertner's names, it has been described here as new.

N. myrtifolia (Gaertn.) J. Thompson, comb. nov.-Fabricia myrtifolia Gaertn., Fruct. 1: 175, t. 35, f.4 (1788) nom. illeg. Type: Endeavour R., Banks and Solander, 1770. Type material is widely distributed, v.s., NSW 133483. It is represented also by Gaertner, l.c., t. 35, f. 4 and Banks and Solander, Ill. Bot. Cook's Voy. 2: 36, pl. 105 (1901). 
N. mjoebergii (Cheel) J. Thompson, comb. nov.-Leptospermum mjoebergii Cheel, J. \& Proc. Roy. Soc. New South Wales 53: 120 (1919).-Holotype: Coleman River, N. Queensland, Dr E. Mjöberg 9.1913 (NSW).

This species resembles $N$. myrtifolia in the structure of its fruit and seed, and the general aspect of its filaments and their arrangement. It differs from that species in a number of features regarded as of some signifigance in Leptospermoideae. It has fewer stamens than $N$. myrtifolia, its anther-cells are opposed either side of a gland terminating a slender filament-apex rather than on the same (inner) side of an expanded and club-like filament-apex, and it has its axillary flowers on unspecialised shoots rather than on the highly modified bracteose shoots found in N. myrtifolia.

\section{Pericalymma (Endl.) Endl.}

Pericalymma (Endl.) Endl., Genera Pl. 1230 (1840).-Leptospermum Sect. Pericalymma Endl. in Huegel, Enum. Pl. 51 (1837).-Type species: P. ellipticum (Endl.) Schauer.

This monotypic genus is reinstated here to accommodate a species which has been united by most authors, including Bentham, Fl. Austral. 3: 110 (1867), with Leptospermum. Pericalymma differs from Leptospermum in a number of characters which are of some significance in the delimitation of groups within Myrtaceae. Conspicuous among these are the characteristic bifurcate (though not sympodial) branching and flowers that are borne on shoots on which the transition from leaves to bracts is gradual rather than abrupt. Also, the ovules are peltate (hemitropous), and, of the several in each loculus, only the lowest develops, forming a single seed occupying the tapering base of the loculus. The seed surface has a close pattern of minute protuberances and is quite distinct from the striate or reticulate surface found on Leptospermum seeds.

Pericalymma ellipticum (Endl.) Schauer in Lehm., Pl. Preiss. 1: 120 (1844)._Leptospermum ellipticum Endl. in Huegel, Enum. Pl. 51 (1837). - Type: King Georges Sound, Hügel, n.v.

Pericalymma crassipes (Lehm.) Schauer in Lehm., Pl. Preiss. 1: 120 (1844).Leptospermum crassipes Lehm., Index Seminum Hort. Bot. Hamburg (1842). - Type: ?Albany, n.v.

Pericalymma floridum Schauer in Lehm., Pl. Preiss. 1: 121 (1844).Leptospermum floridum (Schauer) Benth., Fl. Austral. 3: 110 (1867).-Syntypes: in humidis silvae trans fl. Cygnorum haud procul a vico Guildford, Aug. a. 1839, Herb. Preiss. No. 131; J. Drummond, n.v.

$P$. ellipticum is a species of remarkable variability inhabiting coastal parts of southwestern Australia. Plants of this taxon show variation in pubescence, especially of the hypanthium, length of the deltoid calyx-lobes, size and number of stamens in front of each calyx-lobe, and distension of the base of the main stem. Each of these characters varies independently but all clinally in the same direction, i.e., from north to south to east, and, in the southeast, from inland to coast. A study of the variation pattern in the field may make it possible to evaluate factors influencing the variation. Soil water-logging is obviously of some significance. The entities (endpoints of the cline[s]) which may be distinguishable after a study of this nature, will probably accord with infraspecific forms which in the past have been recognised as the species listed in synonymy above. The wood anatomy of the swollen stem found in the form inhabiting swamps on the southern coast has been examined by P. Baas (1977).

\section{Homalospermum Schauer}

Homalospermum Schauer, Linnaea 17: 242 (1843).-Type species: H. firmum Schauer. 
This genus is reinstated here. It has been included in Leptospermum by most authors, including Bentham, Fl. Austral. 3: 104 (1867). It differs from that genus in a number of features usually considered significant in delimiting groups in the family. Its flowers are borne singly in successive leaf-axils on unmodified shoots, and each anther has two thickened ridges on the back, on either side of the point of attachment of the filament. The ovules are peltate (hemitropous) and such seeds as develop are disc-shaped with a marginal wing and central point of attachment. Homalospermum is represented by a single species found in swamplands of coastal southwestern Australia.

H. firmum Schauer, Linnaea 17: 242 (1843).-Type: [Australiae occid.], Drummond herb. No. 45, n.v.

\section{The Leptospermum suballiance}

All the taxa dealt with in this paper are included by Briggs \& Johnson (1979) in their Leptospermum suballiance. Their assumption of a close relationship between the genera of this suballiance is not invalidated by the recognition of three further genera, or by the recent discovery of a new genus in Western Australia. In fact their interpretation of the Myrtaceous inflorescence, and their terminology for its expression, has brought a new confidence to evaluation of the differences between and within genera of this group.

A key to the eight genera of this suballiance, using characters thought to represent rather fundamental differences between them, is given below.

1. Leaves alternate or, if opposite, then the stamens considerably longer than the petals.

2. Placenta in the upper part of the loculus, with the ovules horizontal to pendulous or all pendulous.

3. Anthers versatile. Seeds unwinged or winged by extension of the testa.

4. Ovules anatropous and oblong.

5. Stamens considerably longer than the petals, the filaments in the bud inflexed so that the anthers are below the stigma ..... $\ldots \ldots \ldots \ldots \ldots \ldots \ldots \ldots \ldots \ldots \ldots \ldots \ldots \ldots \ldots$ Kunzea Reichb. [A genus of c. 30 species; in south western Australia, eastern Australia and New Zealand.]

5. * Stamens not or scarcely longer than the petals, the filaments in the bud incurved towards the stigma $\ldots \ldots \ldots \ldots \ldots . . . . .$. $\ldots \ldots \ldots \ldots \ldots \ldots \ldots \ldots \ldots$ Leptospermum Forst. et Forst. $f$ [A genus of c. 80 species; from southern Thailand, Malesia and the Philippines to southern Papua-New Guinea, through tropical the eastern Australia to southwestern Australia, and in New Zealand.]

4.* Ovules hemitropous and peltate.

6. Flowers occurring singly in successive leaf-axils of an unmodified stem ...................... Homalospermum Schauer [A genus of 1 species; in southwestern Australia.]

6.* Flowers 1-few, each subtended by a bract, at the end of a modified stem which is frondobracteose and usually with the terminal bud aborted ............... Pericalymma (Endl.) Endl. [A genus of 1 species; in southwestern Australia.]

3.* Anthers not versatile. Seeds winged by an aggregation of aborted ovules [A genus of 2 species; in tropical Queensland.] 
2.* Placenta in the lower part of the loculus, with the ovules ascending or erect

7. Stamens free [A genus of c. 12 species; in southwestern Australia.]

Agonis (DC.) Lindl.

7.* Stamens united at the base in an undulating ring broadest in front of each petal

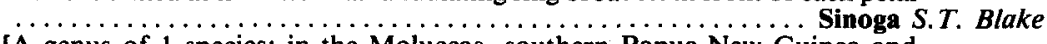
[A genus of 1 species; in the Moluccas, southern Papua-New Guinea and tropical Queensland.]

1.* Leaves opposite. Stamens much shorter than the petals an undescribed genus [A genus of 1 species; in southwestern Australia.]

\section{REFERENCES}

Baas, P. (1977). The peculiar wood structure of Leptospermum crassipes Lehm. (Myrtaceae). Int. Assoc. Wood Anat. Bull. 1977/2: 25-30.

Blake, S.T. (1958). New and critical genera and species of Myrtaceae subfamily Leptospermoideae from eastern Australia. Proc. Roy. Soc. Queensland 69: 77.

Briggs, B.G. \& L.A.S. Johnson (1979). Evolution in Myrtaceae-Evidence from inflorescence structure. Proc. Linn. Soc. New South Wales 102: 208.

Manuscript received 19.10.1981 